\title{
Rhapsodic Shakespeare: V Sambasivan's kathaprasangam / story-singing
}

Poonam Trivedi

\section{(2) OpenEdition \\ 12 Journals}

\section{Electronic version}

URL: http://journals.openedition.org/shakespeare/3590

DOI: 10.4000/shakespeare.3590

ISSN: 2271-6424

\section{Publisher}

Société Française Shakespeare

\section{Electronic reference}

Poonam Trivedi, «Rhapsodic Shakespeare: V Sambasivan's kathaprasangam / story-singing ", Actes des congrès de la Société française Shakespeare [Online], 33 | 2015, Online since 10 October 2015, connection on 03 June 2020. URL : http://journals.openedition.org/shakespeare/3590 ; DOI : https:// doi.org/10.4000/shakespeare.3590

This text was automatically generated on 3 June 2020 .

(c) SFS 


\title{
Rhapsodic Shakespeare: V Sambasivan's kathaprasangam / story-singing
}

\author{
Poonam Trivedi
}

"The singer of tales is at once the tradition and an individual creator". ${ }^{1}$

1 The presence of Shakespeare in the public and popular sphere is increasingly being documented and subject to critical attention. ${ }^{2}$ Yet few would have come across, least of all accounted for, a more novel instance of Shakespeare being performed in Hindu temples, rubbing shoulders with gods and goddesses. And, at the same time, being invoked, by the same performer, alongside Communist icons at Party rallies, entertaining people in clubs and stimulating edgy competitiveness in schools and colleges. And, what is all the more amazing, attracting thousands as audience for what is still remembered vividly as 'mesmerizing' presentations of Shakespeare in a heady mix of narrative and song.

2 This paper tells a unique and hitherto undocumented tale of the phenomenal popularization of Shakespeare among the masses in Kerala, the southwestern-most state of India, through a variant of an indigenous devotional story-telling form, kathaprasangam. It attempts to unravel the reasons for this un-precedented success story of creating a 'Shakespeare commons' in Kerala. It will examine the kathaprasangams of Othello and Romeo and Juliet and will investigate the contribution of the performer, his music, the form and the contexts which nourished it. It will glance at the concepts and methodologies of orality to analyse the modes of composition, performance and reception of this form of story-singing, harking back to early oral traditions, and its vitalisation of Shakespeare. It will argue that apart from the local popularity, the larger significance of such 'oral' renderings is that they tap into and extend, in a particular manner, the residual 'orality' of the plays and the poetry, something which is seldom attended to in the text heavy study of Shakespeare. 
Shakespeare in India has seen several waves and modes of popularization since he began to be performed in the country in 1775, in English, and from 1852 onwards in translation: for instance via Parsi theatre, elocution in schools, quotation in public speeches, and more recently, through the audio cassette industry and of course through films. ${ }^{3}$ But this is a story of recouping an unusual Shakespeare beyond these known forms of popularization and one which is also typical of the Indian situation, that is an eclectic collocation of the sacred and secular, classical and folk, traditional and contemporary, cultural and socio-political.

4 The creator of this achievement was the singer-performer, V Sambasivan (1929-1997), ${ }^{4}$ a foremost exponent of the kathaprasangam, who secularized this form by bringing in stories from folk and contemporary literature to mingle with epic mythologies, as well as translating and adapting world classics like Shakespeare along with Sophocles, Tolstoy and Dostoevsky. His act was simple, like that of the traditional rhapsodes / itinerant minstrels of the past; he was a solo performer, narrating stories interspersed with song and commentary. Accompanied by a few musicians on the harmonium, tabla and cymbals he stitched stories together in song (Gk. rhapto = stitch, ode =song) as he went along. However, to make the narrative come alive, he also enacted the roles of all the characters, putting on and modulating different voices, tones, pitches and gestures suitable for the various roles. Hence, his act was not just solo stand-up singing or narration but a fuller, more dramatic experience of the whole, where one singer-actor performed the roles of all the characters, harnessing into his show the energy and the viscerality of the 'liveness' of theatre. Sambasivan was handsome, had a sonorous voice with depth and range, an innate talent for singing and acting and a love of Malayalam language and literature. He would localize his narratives by interpolating references from local stories and poetry. He developed fifty-five stories, including Shakespeare's Othello and Romeo and Juliet, performing them at over 15,000 different locations / stages, (as stated on his website) not only all over Kerala but also in the UAE for the benefit of the Malayali diaspora (1988).

5 His act proved phenomenally popular: thousands are reported to have flocked to his sessions, particularly those held in the open air within temple precincts. Over a span of forty-eight years, from 1949 to 1996, Sambasivan perfected the mass appeal of his art and can be credited with familiarizing an entire generation across a wide spectrum of classes in Kerala with Shakespeare and other classics in their own language, Malayalam, through their very own idioms, musical sounds and registers. It is still possible to meet people, in the sixty-odd year group, who remember vividly having seen and heard Sambasivan's performances, especially Shakespeare, in childhood, and being completely overcome by them. For instance, the film director, Jayaraaj, who has several awards to his credit, including one for his celebrated adaptation of Othello, Kaliyattam (2004), acknowledges Sambasivan's act as a foundational introduction to Shakespeare. ${ }^{5}$ What is more, the songs that Sambasivan interpolated into the narrative became so well known that they have lingered in the collective consciousness of the Malayali people, becoming detached and taking on a life of their own. And they continue to circulate, being sung informally at parties and get-togethers even today. ${ }^{6}$

6 Thus this becomes a particularly telling tale of the myriad mingled modes in which Shakespeare circulates in modern Indian culture challenging notions of him as an author who speaks only to the high-brow and the educated elite. Through assimilation into a popular, indigenous, free-flowing performative idiom Shakespeare has managed 
to penetrate a far wider range of spectators / listeners than could have been possible through the class-room, theatre or even film.

7 In India, as in Africa and parts of Asia, but unlike in much of the Western world, many early oral forms of poetry and narration have continued to survive into the twentieth century evolving and assimilating new features, modes of performance and music. Bardic singer-poets too are to be found in many parts of India, like the bauls in Bengal and manganiyars in Rajasthan to mention the most well-known, who circulate ancient traditions of folk ballads, choral songs and ritual music. As a matter of fact, all the three stages of orality as identified by Walter J. Ong in Orality and Literacy, "primary" of preliterate cultures, "residual" of the transitional stage and "secondary" of the contemporary age of electronic media dependent on print, may be traced in India in different parts of the country, existing, at times, simultaneously. ${ }^{7}$ Sambasivan may be seen as a modern version of an ancient rhapsode who, as Gregory Nagy has argued in his research on the development of the Homeric tradition, was the "ultimate performer and composer" and whose methods may best be understood through the metaphor of "the aesthetics of sewing," which highlights "both technique and product of poetic craftsmanship" of such a singer of tales. Nagy's elaboration: "the stitcher, one who sews together pieces of fabric already woven is a master craftsman in his own right fashioning something altogether 'new' that is tailor made to suit a given form" is also a summation of Sambasivan's work which gave a new direction to an ancient form. ${ }^{8}$ The performative form which Sambasivan took over, kathaprasangam, was essentially a religious one, deriving from older, allied forms of orality like ramakatha, harikatha and patakam found in all regions in India. These were devotional forms, re-telling stories from Hindu mythology, the epics and Puranas deployed as acts of piety or bhakti. In the original form, usually a single rhapsode poet-singer-instrumentalist-actor would move from village to village performing, reciting and singing his tales of gods and heroes in temples and for patrons. In Kerala, in the wake of the reform movement instigated by sage Narayana Guru in the early twentieth century, this devotional form was appropriated by his disciple C.A. Sathyadevan in 1924 to sing ballads and spread the message of social upliftment for the lower castes. In Sambasivan's hands, this traditional form was further modernized to take on an entirely secular and literary dimension. The linguistic re-organisation of states had also just taken place 1956 and there was a renewal of pride in the region of Kerala and its language Malayalam. Sambasivan's pioneering translation, adaptation and performance of world classics in the kathaprasangam format were also motivated by a desire to expand the ambit of the Malayalam literary and cultural sphere. All this moved the form from the strictly religious space giving it a dynamic variability which made it grow, eventually becoming a highly successful and popular medium for the entertainment and education of the common people, as also a means of their conscientisation towards social and political reform.

8 The context which made this possible was the ferment stimulated by the Communist movement in Kerala. This state was the first in India, and Asia, to elect a Communist government to power in 1957 and the Communists have continued to dominate its politics since then. Along with agrarian and labour reforms, the Communist 
government initiated reforms in education too. Kerala already had a high literacy rate compared to other parts of the country (partly the result of the earlier religious reform movement) and the rise of Communism spearheaded the establishment of far reaching initiatives like the Literacy Movement, Arts Club Movement, Library Movement and the Progressive Literary Movement in Kerala. V. Sambasivan received his energy from these and also contributed to their spread in turn. He was a member of the Communist Party of Kerala and its radical student wing AISF (All India Student Federation) during his days at Sree Narayan College, Kollam, and like so many adherents, he was motivated to utilize his talents for a progressive purpose. His personal entry into katha singing was somewhat fortuitous, as events in real life turn out to be. He was short of money to take admission in college, so he organized a katha session to raise funds. He went on to acquire a name for his singing skills in his college days and though he initially took up a job as a teacher after finishing his studies, he soon left it to become a full-time rhapsode or kathaprasangak. During this period, public performance, especially theatre was promoted by the Communist Party as a means of mass mobilization, and theatre and performative arts competitions in schools and colleges became popular and powerful means of spreading the message of the Left.

The Left movement in Kerala is noted for its moderation of ideology in practice. It promoted caste, not class equality, peasant, not state, ownership of land, and more to our purpose, the accommodation of religion (Hinduism 56\%, Islam $25 \%$ and Christianity $20 \%$ ) within the aegis of the state. ${ }^{9}$ Hence it was entirely acceptable for Sambasivan to adapt for secular purposes a Hindu religious practice of devotional singing. Western classics in religious music could now co-exist and, in fact, gave an additional heft to Sambasivan's act. The nature of the audience he was thus able to marshal, numbering five to six thousand for the temple recitals, and more during the party political gatherings, was an increasingly diverse mix of class and religion. His performances in the beginning were held mostly in temple precincts during festivals (cultural activity along with religious celebration is a norm in Kerala). But with his Communist party affiliations, he was also conscripted to perform as a curtain raiser or finale for political party rallies. And as his popularity grew, he was invited to perform in college concert halls and in clubs. His rhapsodic Shakespeare acquired an amazing reach: from ordinary people of the working and lower middle classes, to students and housewives, to party workers, to professionals, and soon he achieved a pop-star like cult status with a committed following. ${ }^{10}$ Thus the kathaprasangam form received a fillip via Shakespeare and other western classics, and along with the concerted efforts of two other renowned exponents of the same, Ketamangalam Sadanandan and NP Kurup, it was moved from the religious to the socially progressive sphere, with the art-form being acknowledged as "a deadly weapon" (The Hindu, 14 April 1998) against social injustice. As a matter of fact, Sambasivan was jailed during the 1975 Emergency for narrating stories from Left writers. This seemingly contradictory conjugation of the religious with the secular, of Shakespeare's love tragedies and progressive socialism, is what makes this a particularly revealing and 'telling' tale: modernity in India has been about accommodating tradition and even the regional radicalism of Kerala was compromised. The plays of Thoppil Bhasi for instance, identified with the KPAC (Kerala People's Arts Club) movement of the 1950s, were propagating social transformation but they nevertheless remained centered on love; politics and affect went together. ${ }^{11}$ It is a truism that Shakespeare finds directions through indirections: both Othello and Romeo and Juliet were introduced by Sambasivan as famous examples of "world literature" 
written by William Shakespeare, and the consciousness of the colonial pedigree of Shakespeare seemed to have receded into the past.

\section{II}

Sambasivan's mass appeal had another dimension. It was not only the progressive Left context or the harnessing of a known religious form, but also his rhapsodic performance. The Cambridge Advanced Learner's Dictionary gives "expressing powerful feeling" as one of the primary meanings of rhapsodic, in addition to the somewhat negative, common usage, meaning "extravagantly emotional." And it is the former semantic sense that I use to elucidate the "rhapsodic." In a manner akin to the rhapsodes of the Greek tradition who did not just reduplicate but recomposed as they performed, Sambasivan developed full-length over two-hour-long (one hour in the later recorded versions available today) dramatized narrative of the classics, both Western and Eastern, which he chose to perform. Both his Othello and Romeo and Juliet kathaprasangams were faithful versions of the original in Malayalam translation, retaining most of the plot, names of characters and locations. In their edited forms they come across as more intense and rhapsodic. Sambasivan's was a live performance and its chiefly auditory experience produced a "readjusting [of] the ratios of sensory experience" as observed by Julie Sanders, with regard to Shakespearean afterlives in music. ${ }^{12}$ Walter Ong too has some acute observations on the psychodynamics of sound as opposed to sight. "Sound" he says, produces "interiority," it "incorporates" while sight "isolates." Sound "pours" into you while "sight situates the observer outside what he views." While vision is the "dissecting" and "clarifying" sense, sound is the "immersive" "unifying" sense, creating "harmony."" 13 Sambasivan's primarily aural performance was able to stitch together the orality and music of the katha tradition to Shakespeare's words and poetry, unifying and harmonising these diverse elements for his audiences. With no distraction of movement or visuality, the oral dramatization and singing concentrated greater attention on the words and their intonation, pitch and emotion with which they were inflected. A greater felt intimacy, interiority and involvement with the characters and their conflicts were generated.

11 The semiotics of the indigenous performative genre too added to the rhapsodic effect. Kathaprasangam, like its predecessor, harikatha, had evolved from the basic devotional form of the kirtana which is group singing usually led by a poet-singer, preaching to a congregation.

The mode of singing is a steady building up, a heightening of emotionalism and passionate praise which is meant to induce a surrender of the self, leading to a final crescendo which is said to end in a darshana or an epiphanic experience and a glimpse of divinity or truth. Sambasivan's Shakespeare's success was also in some measure based on the dynamics of this performative genre and his modernization of it. In its crescendo like buildup and its epiphanic apprehension at the end, it is not unlike the emotional graph of a tragedy. Further, as with all such oral traditions, there is an inherent flexibility for musical improvisations and inventiveness which is often utilized for the interpolation of a wealth of contemporary social and political asides. Some versions of kirtana deploy the lover-beloved (sacred and profane metaphor) motif in their praise of the deity which afforded further space for ambiguity and double entendre. Hence, even while these performances are occasions of serious prayer and 
piety, they encapsulate within their processes scope for extra spiritual dimensions. The sacred and the secular often go in tandem within this tradition. Sambasivan succeeded also because his very local audiences were attuned not just to the improvisatory structure and revelatory endings conducted through the song and narrative of the performative genre, but also because investment in emotion as the centre of all art is part of their indigenous aesthetic and literary theory, of the rasa siddhanta, which still animates and determines a large swathe of the creativity in the arts around them. The ubiquitous presence of songs in film, a medium vérité, is an obvious instance.

\section{III}

13 It is not an accident that Sambasivan chose well known love tragedies for adaptation (he also did Anna Karenina and Antigone), because dramatic emotionalism was at the heart of his performance. All the dramatis personae and their key dialogues were dramatized by Sambasivan in different voice modulations and facial expressions; key lines, moments, moods and emotions of Shakespeare's text were put into song, often repeated for choric effect. The effect was like listening to a live radio play, but by one performer, which was animated by his frequent gestures. His translations were an apt mix of the poetic and the colloquial for wide accessibility. They were laced with a humorous turn of phrase and peppered with pointed comments from the narratorial perspective / voice. As noted by Douglas Lanier, audio Shakespeare recalibrates and produces a fresh "textualisation and interiorisation." ${ }^{14}$

Shakespearean tragedies embed an incipient moral lesson and Sambasivan's progressivism lay in presenting it critically, not didactically, but indirectly, as dramatic irony, emphasizing the pathos of the situation. For example, his comment on Othello: "a man who proudly praises his wife as the epitome of virtue whom he will never doubt" is repeated when Othello is consumed by murderous rage stroked by Iago's machinations, fore-grounding the irony by reminding us that "this is the same man who had earlier said that my wife is a goddess of virtue and I would never doubt her, now says with the same tongue that she is a whore, a monster who deceives you with her beautiful smile." ${ }^{15}$ His rendering of the play Othello interprets it as a tragedy of misunderstandings deliberately precipitated by Iago as an act of revenge for being passed over for promotion as Lieutenant. But right from the start of the narration, Sambasivan's leftist leanings emerge when he emphasizes and makes the audience empathize with Othello's "otherness": being born in poverty, his subjection to slavery, his rise to eminence on the battlefield and his repeated denigration because of his black complexion by Brabantio and Iago, "karumban" and "blackie". On the other hand, Othello's difference juxtaposed with Desdemona's radiance he marks sympathetically and poetically as "Amavasi" versus "Purnima", "moonless night" juxtaposed with the "full moon night." Further, his progressivism is seen in the open sympathy for the women in the play: not only is Desdemona beauty and perfection incarnate and Emilia, the loyal and sensible one, Bianca too is elevated and dignified. She is compared to Vasavadutta, the lovelorn courtesan heroine of Malayalam poet Kumar Asan's wellknown poem of the same name, who falls in love with the client/hero. Sambasivan also gives voice to Othello's mother and to the witch who gave her the fatal handkerchief, interpolating a moving song about Othello's explanation of its magical qualities. Apart from these localizations, the katha narrative runs faithful to the original retaining 
names, place names and much of the imagery. Iago is sly and appropriately Machiavellian and Othello collapses quickly under his insinuations. At the end Othello strangulates Desdemonain a mad fury, but after stabbing himself, in this narrative, hethenturns back to the dead Desdemona with the words "I could not kiss you much, killed you instead, but will now leave by kissing you" - his love for her underlined and restored.

Likewise, Sambasivan's equally popular Romeo and Juliet foregrounds the menace of feuding families and the vitiation of social peace. It enframes this political message by beginning, more dramatically, than the play, with the sounding of hooves and the entry of the Prince to control the fighting. The Capulets and Montagues are warned and described as "arch enemies who belong to the same clan, like poisonous snakes waiting to bite each other." At the end of the play, when the Prince reiterates how "Fire of your hate had spread and burnt down the heavenly abode of love [...] in the two children", the socio-political dimension of the story is emphasized. The katha narrative, while retaining most of the plot, highlights the purity of the lovers too, celebrating their "free and boundless" hearts (swatantra) which attain their desires, despite the family enmity. Romeo has no earlier infatuation for Rosaline here and hence can be congratulated by Friar Lawrence for "feasting at the enemy's" like a "true Christian". The translation and abridgement which cut out some of the wordplay, give Juliet, interestingly, more agency here. "If I will marry, my husband will only be Romeo, Romeo Romeo" she tells Lady Capulet. "I don't like this marriage (to Paris)" she says more forthrightly than in the original. In her later plea to the Friar to help her out of her dilemma, the purity of her heart is emphasized: "We, whose hearts were connected, were married by the blessing of Gods, how can I keep this relation pure till I die? [...] otherwise I'll kill myself." And in the dialogue with the Friar at the end, when she wakes and finds Romeo dead, and the Friar offers to take her to a convent because the family will sell her again in the marriage market, she strongly rejects this option to stay alive, and only then stabs herself. These few added emphases apart, the Romeo and Juliet prasangam is closer to the Shakespearean original than the Othello mainly because so much more of the imagery is effectively translated communicating fully the moods of exhilaration and pathos of the play. Starting from the beginning, from "love as a fume of sighs [...] a sea of tears" to "holy palmers' kiss" to the nightingale and the lark, to the "wedding cheer to a sad burial feast" to amorous Death, to "eyes, look your last", and many more such, all the well-known images are skillfully incorporated in the local idiom. Sambasivan's versions are socially and politically pointed mainstream interpretations of the play, but their real merit lay in the affective involvement they were able to generate. With subsidiary characters and scenes edited out, the emotionalism and pathos were concentrated on the main events and further enhanced by interpolated comments. For instance, when Romeo tries to break open Juliet's tomb, "skulls and bones laugh at him", while "the trees shed tears of dewdrops." The songs, also substantially incorporating Shakespearean imagery, along with the music added to the immersive effect, making the whole so vivid that audiences remained riveted for hours, and even when played back today - it is available on YouTube - listeners are startled and moved by the range of feelings aroused despite being over-familiar with the story and the plot. 
Shakespeare's world in the sixteenth century was what Walter Ong describes as one of "residual orality," a transitional stage between orality and literacy. It is recognized that all his plays contain elements of the oral, unwritten culture of his time, like references to "fairy tales, gossip, superstitions, ballads, jigs and mummings." ${ }^{16}$ A major part of the Elizabethan population was illiterate and though many songs and ballads were being printed and sold, they still continued to be produced and transmitted orally. "'Orality and writing were competing forms of communication within the Renaissance playhouse" too, observes Emma Smith, ${ }^{17}$ and Shakespeare's plays bear signs of orality in their rhetorical devices and elocutionary practices. Critical and editorial practice however has till recently looked upon orality as a corrupt residue which needs weeding out. The acceptance of the textual fluidity of the Shakespearean play, on the other hand, has stimulated a rethinking about orality: Gary Taylor has posited the notion of "a lost orality" in Shakespeare, an "unwritten paratext" which he deplores being filled in and "fixed" by editors in the current bibliographic practice (for example the stage directions). ${ }^{18}$

The oral elements of Shakespeare's plays have also been seen to have been recouped in another, more substantive manner, in translation. Deborah Seddon has shown how South African writer Solomon Plaatje's translations in Setswana were based on "a sense of equivalence of function between Shakespeare's plays and African orature." And that his free translations were a reactivation of the oral elements of Shakespeare, along with a dissemination of the Setswana orature. For example, the translation of the very title of Comedy of Errors, done in a free idiomatic manner, as Diphosho - phosho, (mistakes upon mistakes) and not the literal khomedi ya diphosho is an indication of how "Shakespeare's orality" is harnessed and fore-grounded. ${ }^{19}$ Several such instances from Sambasivan's translations too, transposing Shakespearean images into fluent idiomatic phrases in Malayalam can also be pointed out. For instance, the references to "bones" and "joints" of the forefathers, which Juliet hallucinates will haunt her if she wakes up early in the tomb $\left(4.3 .40,51^{20}\right)$ and to the "eyeless skulls" (5.3.126) that the Friar notes in the tombs, are deftly conflated into a colloquial rhyming phrase "talayodukalum tudayellukalum" meaning "skull and thigh bone" which is repeated in the last scene to add to the pathos.

It is the contention of this paper that Sambasivan's extraordinary oral renderings in translation into Malayalam and kathaprasangam do not simply speak out or 'oralise' Shakespeare's text, but give back to Shakespeare what was Shakespeare's, the incipient orality of the local popular and folk which is intricately interwoven into the texts. Further, the oral performativity crystallizes and enhances the affective like in a rhapsody. Sambasivan's emotive and affective rhapsodizing of Shakespeare might come across as melodramatic to Western ears but its huge success underscores the power and pull of expressed feeling and emotion in the plays. In the dominant trend of academics where literary criticism has been held in thrall by theories from linguistics, philosophy, politics and sociology, the world of affect which constitutes the very life-blood of drama, its quintessence, which animates the characters and connects the audiences, has been sidelined. A look at other non-Western cultures and their performative aesthetics and treatment of Shakespeare may help us recoup some lost ground as far as Shakespeare's popularity is concerned. 


\section{NOTES}

1. Albert Bates Lord, The Singer of Tales, ed. Stephen Mitchell and Gregory Nagy, 2nd edition, Cambridge, MA, Harvard University Press, 2000, p. 4.

2. Acknowledgements: I would like to thank Haritha P. for translation from Malayalam, Dr. Vasanthakumar Sambasivan (Sambasivan's son and also a practitioner of kathaprasnagm) and Dr. K. Satchidanandan for information about Sambasivan, kathaprasangam and its contexts.

3. See Poonam Trivedi and Dennis Bartholomeusz, eds., India's Shakespeare: Translation, Interpretation and Performance, Newark, University of Delaware Press, 2005 and New Delhi, Pearson, 2006.

4. See http://www.vasanthakumarsambasivan.com/family.php the website of Sambasivan's son for a history of the family (last accessed 1 September 2015).

5. As told to Mark Thornton Burnett in Shakespeare and World Cinema, Cambridge, Cambridge University Press, 2013, p. 71.

6. As told to me by Haritha P.

7. Walter J. Ong, Orality and Literacy, London, Routledge, 2002 [1982].

8. Gregory Nagy, Poetry as Performance: Homer and Beyond, Cambridge, Cambridge University Press, 1996, p. 60, 75.

9. For Communism in Kerala see Thomas Johnson Nossiter, Communism in Kerala: A Study in Political Adaptation, Berkeley, University of California Press, 1982.

10. As communicated by K. Satchidanandan and Haritha P.

11. See Dilip M. Menon, "Lost Visons?: Imagining a National Culture in the 1950s", in Alice Thorner, ed., Land, Labour and Rights, London, Anthem Books, 2001, p. 268.

12. Julie Sanders, Shakespeare and Music: Afterlives and Borrowings, Cambridge, Polity Press, 2007, p. 10.

13. Ong, op.cit., p. 70.

14. Douglas Lanier, "Shakespeare on record" in a Companion to Shakespeare and Performance, ed. Barbara Hodgdon and W.B. Worthen, New York, Wiley Blackwell, 2005, p. 417.

15. Quotations from Othello and Romeo and Juliet are from the You Tube versions available at: Othello, https://www.youtube.com/watch?v=x-oiH6D5H4Y (last accessed 1 September 2015) and Romeo and Juliet, https://www.youtube.com/watch?v=JvMFRf5mmWw (last accessed 1 September 2015).

16. Michael Dobson and Stanley Wells, eds., The Oxford Companion to Shakespeare, Oxford, Oxford University Press, 2001, p. 328.

17. Emma Smith, Shakespeare's Tragedies: A Guide to Criticism, Oxford: Blackwell, 2004, p. 308.

18. Gary Taylor, William Shakespeare: A Textual Companion, eds. Stanley Wells, Gary Taylor, John Jowett and William Montgomery, Oxford, Oxford University Press, 1987, p. 2-3.

19. Deborah Seddon, "The Colonial Encounter and the Comedy of Errors: Solomon Plaaatje's Diphosho-phosho" in The International Shakespeare Year Book, Vol. 9, eds. Graham Bradshaw and Tom Bishop, Farham, Surrey, Ashgate, 2009, p. 67.

20. All quotations are from Romeo and Juliet, ed. Brian Gibbons, The Arden Shakespeare, London, Methuen, 1980. 


\section{ABSTRACTS}

The paper documents a unique tale of a phenomenal popularization of Shakespeare among the masses in Kerala, the southwestern-most state of India, through a variant of an indigenous devotional story-telling form, kathaprasangam. It unravels the reasons for this un-precedented success story of creating a 'Shakespeare commons' in Kerala. It examines the kathaprasangams of Othello and Romeo and Juliet and will investigate the contribution of the performer, his music, the form and the contexts which nourished it. It will glance at the concepts and methodologies of orality to analyse the modes of composition, performance and reception of this form of storysinging, harking back to early oral traditions, and how it communicated Shakespeare. It will argue that apart from the local popularity, the larger significance of such 'oral' renderings is that they tap into and extend, in a particular manner, the residual 'orality' and expressivity of the plays and the poetry, something which is seldom attended to in the text-heavy study of Shakespeare.

Cet article étudie la réception populaire de Shakespeare dans l'état du Kerala, au sud-ouest de l'Inde, à travers une variante exceptionnelle d'un récit dévotionnel traditionnel de cette région, le kathaprasangam, et explique les raisons de cette extraordinaire réussite. L'analyse des kathaprasangams d'Othello et de Roméo et Juliette permettra de mettre en lumière le rôle de l'acteur, de la musique, de la forme et des contextes qui ont nourri la représentation. Les méthodologies de l'oralité seront utilisées afin de mieux comprendre les modes de composition, de représentation scénique et de réception de cette forme de récit chanté, qui renvoie à d'antiques traditions orales, ainsi que la façon dont Shakespeare est ainsi transmis. Au-delà de la popularité locale, de telles interprétations oralisées ont des répercussions plus larges, car elles puisent dans « l'oralité » et l'expressivité résiduelles des pièces et poèmes, qu'elles développent, aspects qui ne sont pas toujours développés dans les études shakespeariennes.

\section{INDEX}

Keywords: appropriation, kathaprasangam, orality, Othello, rhapsode, Romeo and Juliet, Sambasivan, Shakespeare in India

Mots-clés: appropriation, kathaprasangam, oralité, Othello, rhapsode, Roméo et Juliette, Sambasivan, Shakespeare en Inde

\section{AUTHOR}

POONAM TRIVEDI

University of Delhi, India 